\title{
Interplays among R\&D spending, patent and income growth: new empirical evidence from the panel of countries and groups
}

Ramesh Chandra Das

Correspondence: ramesh051073@ gmail.com

Vidyasagar University, West Bengal, India

\begin{abstract}
Industrial houses and governments of different countries and groups spend a sizeable amount of their earnings upon research and development activities to create new products and obtain patents for them. The short-run motive is to get patents, and the long-run motive is to influence income growth of the countries. The empirical findings so far are skeptical on the effects of research and development (R\&D) spending. The present study further investigates the long-run associations and short-run dynamics among R\&D spending, number of patents and per capita income growth in the panel of countries and groups for the period 19962017. Using VAR model for the panel data, the study observes that R\&D spending, number of patents and per capita income growth have no long-run equilibrium relations but in the short-run, income growth and number of patents make a cause to R\&D spending. However, there are weak causation from patents and R\&D spending to income growth rates. The study thus recommends for controlling unfair competition on spending on R\&D head and getting patents since it increases the magnitudes of social cost.
\end{abstract}

Keywords: R\&D share, Patents, Per capita income growth, VAR, Panel unit roots, Panel cointegration, Panel causality

JEL codes: O3, O4, E24, F2, O5, C32, C510

\section{Introduction}

Continuous efforts on research and development (R\&D) create perpetual knowledge capital which is one of the bases of the economic growth to be endogenous. With the stock of physical capital, a country can grow through the creation of knowledge where knowledge capital is treated as the positive function of stock of physical capital. New inventions through efforts on $R \& D$ activities get protected by approval of patents rights. Further new research brings up new goods which are used as intermediate inputs for further invention and innovations. There is a continuous process of creation of variety of products under the system of monopolistically competitive market

(c) The Author(s). 2020 Open Access This article is licensed under a Creative Commons Attribution 4.0 International License, which permits use, sharing, adaptation, distribution and reproduction in any medium or format, as long as you give appropriate credit to the original author(s) and the source, provide a link to the Creative Commons licence, and indicate if changes were made. The images or other third party material in this article are included in the article's Creative Commons licence, unless indicated otherwise in a credit line to the material. If material is not included in the article's Creative Commons licence and your intended use is not permitted by statutory regulation or exceeds the permitted use, you will need to obtain permission directly from the copyright holder. To view a copy of this licence, visit http://creativecommons.org/licenses/by/4.0/. 
structure. The industrial houses or the R\&D firms obtain patents for their new inventions through the laws of intellectual property rights and sell the monopolized products in the market to maximize profit. There are other benefits, too. Increase in $R \& D$ activities upon product innovations leads to increase in opportunities of income earnings from all fronts due to low cost of production through the spillover effects and positively affects level as well as growth of national incomes of the countries and the world as a whole (Kwack \& Yang, 2006; Kuo \& Yang, 2008; Gulmez, \& Yardımciog `lu, F., 2012; Gocer, 2013; Gumus \& Celikay, 2015; Das \& Mukherjee, 2019). Hence, R\&D activity allows the increasing returns to scale to be applicable in the production system leading to high production with low costs of production and thereby influence income at least at some country levels. However, there is a twofold cost to this trade-off. Nordhaus (1969) pointed out that the opportunity cost that innovation consumes, through $R \& D$ expenditure, on resources that could be put to other uses and as the amount of cost reduction from innovation from longer patent length increases, society waits longer for the full benefits of the innovation to materialize. That is why the existing empirical observations such as in the works of Levin, Klevorick, Nelson, and Winter (1997), Heller and Eisenberg (1998), Ballot, Fakhfakh, and Taymaz (2001), Hall (2007), Jaffe and Lerner (2004), Samimi and Alerasoul (2009), Boldrin and Levine (2013), Bozkurt (2015), Williams (2017), and Das and Mukherjee (2019) reveal that R\&D spending do not necessarily improve the real income of the concerned countries, although in some cases, it positively affects the firms' performances.

Back to the history of the theories of economic growth, the post-Keynesian Harrod-Domar growth theory emphasized the importance of investment and savings for encouraging growth. The neoclassical growth models by Solow and Swan criticized the post-Keynesian growth models since increase in savings and investment could not produce long-term growth effects. Solow (1956) and Swan (1956) suggested that exogenous technological progress was the crucial factors in the growth process as it could reduce the value of the incremental capital-output ratio or increase the efficiency of capital. Later, Romer (1990) and Lucas (1988) pioneered the role of endogenous technological progress which incorporated R\&D development into economic growth model as an endogenous variable and proved the growth process to be perpetual. Grossman and Helpman (1991), Barro (1991), and Aghion and Howitt (1992) further developed the endogenous growth theory in the globalized world, and the outputs of their efforts were still continuing in terms of increasing income. The networking between $R \& D$ investments and income growth has been elaborated by Aghion and Howitt (1992). To them, each innovation generates new intermediate goods which are then used to produce final goods more efficiently. Economic growth is the result of innovations, skilled labour force and productivity of research. In the later periods, studies that followed the abovementioned models are Blackburn, Huang, and Pozzolo (2000), Lee (2005), Grossmann (2007), and Khan, J.,\& Khattak, N.U.R. (2013), among others.

Under the above backdrop, the present study attempts for new empirical investigations on the interplays among R\&D spending, number of patents and growth of per capita income in a panel of the list of leading countries and groups in $R \& D$ spending for the period 1996-2017. 


\section{Review of literature}

The R\&D-patent-income nexus has been prominent in three countries, USA, Japan and China. The USA has approached intellectual property right strategically and created an intellectual property (IP) infrastructure. On the other hand, Japan has strong leadership from the Prime Minister to develop Japan into an "IP nation". China now has an increasingly well-developed IP system, and the Chinese Government is aware of its shortcomings and is willing to address them. Although these three countries are more concerned on this issue, the empirical evidences show the relationships among these three factors are not confined to them only. We present a list of related literature on these three factors which establish mixed results at country and group levels.

\section{Studies on patent and R\&D}

In their study on whether patenting negatively impacts R\&D activity in a panel of 88 countries over 1996-2003, Almeida and Teixeira (2007) found mixed support to the negativity of patent on $R \& D$ investment. The accumulated patents positively impact R\&D intensity for the set of less developed countries whereas no statistically significant effect emerges in the case of higher developed converge clubs. Danguy, de Rassenfosse, and van Pottelsberghe de la Potterie (2009) reinvestigated the empirical failure to establish a clear link between $R \& D$ efforts and patent counts at the panel of 18 industries over 19 countries and revealed that the R\&Dpatent relationship is affected by research productivity, appropriability propensity and strategic propensity factors and that the current patent hype is essentially the result of a globalization phenomenon.

Boldrin and Levine (2013) observed that there was no empirical evidence that patents served to increase innovation and productivity, unless productivity was identified only with the number of patents awarded. Further they asserted, while patents could have a partial equilibrium effect of improving incentives to invent, the general equilibrium effect on innovation could be negative, and thus, they prescribed for abolishing patents entirely and emphasized upon other legal instruments. Sierotowicz (2015) evaluated the efficiency of R\&D expenditure from the patent activity in 28 European Union (EU) countries for the period 1999-2013 and concluded that the increase in total intramural expenditure on R\&D activities in the business enterprise sectors of the ten leading EU countries made a cause to the increases in the patenting activity of the sector in the long run. In another study, Otomo (2017) examined the impact of patent applications and R\&D expenditure in the USA and EU, taking firm size, governments' interventions and financial performance. It revealed that patents were exponentially increasing in number, only gaining diminishing marginal returns and so it would be fast to say that patents were detrimental to $R \& D$ expenditure as they shaped a crucial part of providing financial incentives for new and potential innovators. In a very recent study, Altuzarra (2019) provides empirical evidence on the link between firms' R\&D expenditure and patent registrations in a panel of Spanish manufacturing firms for the period 1990-2013. The results provide support for a bidirectional causal relationship between R\&D and patents. 


\section{Studies on R\&D, patent and growth}

In a path-breaking study, Levin et al. (1997) asserted that improving the protection of intellectual property is not necessarily socially beneficial. The working of monopoly power behind obtaining patents leads the market to be inefficient, which means patents winning are not good for the economy in the long run. With near-similar observation, Heller and Eisenberg (1998) were alarmed that the recent proliferation of intellectual property rights in biomedical research implied a different tragedy, an anti-commons, in which people underuse scarce resources. Thus, to them, privatization of biomedical research must be more carefully organized, otherwise, more intellectual property rights might lead ironically to a smaller number of useful products for improving human health.

In their study, Ballot et al. (2001) examined the effects of R\&D and human capital stock on productivity of firms in France and Sweden using panel data for the period 1987-1993. The results show a significant role of $R \& D$ and stock of human capital in the determination of the firm's productivity in both the countries.

Chou (2002) examined the sources of economic growth in Australia for 1960-2000 by adapting the concept of 'global discovery of new ideas' and showed that the Australian economy is clearly not on its steady-state balanced growth path, although it has benefited from increases in educational attainment and research intensity.

The roles of investment rate, R\&D, education and size of government upon the long= run economic growth in Korea for the period 1971-2002 has been examined by Kwack and Lee (2006). The study revealed that public and household expenditure on education and R\&D investments were the major contributors to innovation and improvements in the quality of labour. For examining the R\&D-economic growth relationships in Organization of Economic Cooperation and Development (OECD) countries, Falk (2007) observed that higher R\&D investment was positively related to growth domestic product (GDP) growth in working age populations.

$\mathrm{Hu}$ and Jaffe (2007) were skeptical on the issue that even within the technologically advanced world, there was surprisingly little empirical evidence for the proposition that stronger intellectual property right regimes produced faster innovation. Moreover, to them, since investment in innovation is likely to be subject to decreasing returns, extension of strong intellectual property rights to all countries is unlikely to be globally efficient. In another study, Kuo and Yang (2008) investigated the effects of knowledge capital and technology spillover on regional economic growth in China. The results revealed that $R \& D$, capital and technology import contributed significantly to the economic growth in China.

In their study, Samimi and Alerasoul (2009) examined whether R\&D expenditure affected economic growth for 30 developing countries for the period 2000-2006. It revealed that $R \& D$ expenditures had no direct effect on economic growth and mentioned that the underlying reason was insufficient resources allocated to $R \& D$ activities of the selected countries. In a study for China, Wu (2010) depended on the provincial data to examine the role of $R \& D$ on innovation and economic growth. It revealed that $R \& D$ had a positive effect on the regional innovation rate, and that innovation had a positive effect on productivity and consequently economic growth in China.

Gulmez, and Yardımciog $`$ lu, F. (2012) produced the positive effects of R\&D activities upon income in 21 OECD member countries for the period 1990-2010 and revealed 
that a $1 \%$ increase in R\&D expenditures led to an increase in economic growth by $0.77 \%$ in the long run. With respect to Indian pharmaceutical industries, Sharma (2012) attempted to see the influence of R\&D expenditure upon the firms' performance of the industry for the period 1994-2006. It was observed that R\&D intensity had a positive and significant effect on the total factor productivity of the pharmaceutical industries. In a state level study for US, Blanco et al. (2013) estimated the impact of R\&D on the total factor productivity and output in the private sector for the period 19632007. It observed that $R \& D$ had a large effect on both output and total factor productivity at the state level in the long run and the R\&D elasticities were either stable or increase slightly after 1993. The study of Gocer (2013) finds a positive association between $R \& D$ expenditure and economic growth in 11 developing countries from the Asian region covering the period 1996-2012. It was also observed that the contribution of a $1 \%$ increase in $R \& D$ expenditures made acceleration of economic growth by $0.43 \%$. Inekwe (2014) examined the role of R\&D spending on economic growth of developing economies for the periods 2000-2009. The result revealed a beneficial impact of R\&D spending on economic growth in developing countries. The effect of R\&D spending on growth is positive for upper middle-income economies while insignificant in lowerincome economies.

In another research, Bozkurt (2015) tested the relationship between R\&D expenditures and economic growth in Turkey for the period 1998-2013, and the empirical findings obtained suggested that there was unilateral causality from economic growth to R\&D for the country. Williams (2017) argued that given the limitations of the existing literature, still there was no credible empirical evidence on the apparently simple question of whether stronger patent rights encouraged research investments into developing new technologies. In recent study, Gumus and Celikay (2015) empirically tested the relationship between R\&D expenditures and economic growth for the panel of 52 countries of different status of developments for the period 1996-2010. The study observed that R\&D expenditure had a positive and significant effect on economic growth for all countries in the long run. Using historical data for 1600-1913 on USA and 14 Western European countries, Chen (2015) arrived at a significant positive effect of patent laws on economic growth in different specifications of fixed effects, random effects, time effects, dynamic panel GMM, and difference-in-differences models. Freimane and Băliņa (2016) examined the empirical relationship between R\&D expenditures and economic growth in the panel of European Union member states for the period of 2000-2013 and arrived at the conclusion that the former had significant impact upon the latter. A study with different flavor by Choi and Yi (2018) investigated the impact of internet facility upon the inter-linkages between R\&D expenditure and economic growth in a panel of 105 countries during 1994-2014. It revealed that the effects of $R \& D$ expenditure on economic growth were influenced positively by the Internet facility.

In a very recent research effort on whether $R \& D$ spending influence levels as well as growths of per capita incomes in the leading ten countries and four groups in the R\&D list, Das and Mukherjee (2019) arrived at the conclusion that R\&D expenditure and per capita GDP growth rates have long-run associations for high-income and upper middle-income groups along with Japan, Germany, South Korea, France, UK, India, and Brazil without error corrections. Also that per capita income growths make cause 
to R\&D for OECD, upper middle-, and low- and middle-income groups along with Japan, and reversely, R\&D is the cause to per capita incomes for India, Russia, and Brazil. Further, the bilateral causality is revealed between the two for USA, China, and South Korea. All the results of the study are at individual levels with two variables, and hence, consideration of panel data with more than two variables in a vector autoregressive (VAR) structure might have produced more acceptable results.

\section{Rationale of the present study}

The review of the existing studies so far gives us the ideas about the interlinkages among R\&D, patents and incomes of different countries and panels with mixed conclusions. No studies so far have attempted for covering the leading countries and groups in R\&D spending and also their panels in a multivariate system. The present study has tried to fill the gap in the literature and examined the interplays among the three variables in a panel data VAR format to produce new empirical evidence.

\section{Theoretical framework}

We write the form of the production function as used by Romer (1987, Romer, 1990) on the incorporation of product variety generated through R\&D activities as follows:

$$
Y_{i}=A L_{i}^{1-\alpha} \cdot \sum_{j=1}^{N}\left(Z_{i, j}\right)^{\alpha},
$$

where $Y_{i}$ is the output of the $i$ th industry, $L_{i}$ is the unit of labour used in the $i$ th industry, $Z_{i, j}$ is the unit of intermediate products $(j)$ used in the $i$ th industry for its one-unit production, $A$ is the overall efficiency and $0<\alpha<1$. To see the effect of increase in $N$, the number of variety products as intermediate inputs, suppose that the intermediate goods can be measured in common physical unit and all are employed in the same quantity, $Z_{i, j}=Z_{i}$. The modified production function is thus

$$
Y_{i}=A L_{i}^{1-\alpha} \cdot\left(N Z_{i, j}\right)^{\alpha}=A L_{i}^{1-\alpha} \cdot\left(N Z_{i}\right)^{\alpha} \cdot(N)^{1-\alpha}=Y_{i \cdot} \cdot(N)^{1-\alpha}
$$

The production function now exhibits increasing returns to scale which is explained by the number of product term $(N)^{1-\alpha}$.

Once the products get invented, the R\&D firms obtain patents which allow them to charge monopolized prices. That means numbers of patents can be the substitutes for new invention through $R \& D$ spending. The aggregate production function of the entire economy can thus be written as

$$
Y_{i}=f(L, P),
$$

where $P$ is number of patents. In the per capita terms of the production function, it becomes

$$
y_{i}=f(p),
$$

where $y_{i}$ is per capita output and $p$ is per capita number of patents. Further the number of patents depends on the amount of R\&D spending $(r)$. So the revised intensive form of production function is 


$$
y_{i}=f(p(r)), f^{\prime}>0
$$

Hence, growth rate of per capita output is directly related to the growth of number of patents and indirectly to growth of R\&D spending. This means

$$
\dot{y}_{i}=f(\dot{p}(\dot{r})),
$$

where the figures in the dots in the heads represent the respective growth rates of the variables.

\section{Data and empirical methodology}

The study considers top ten countries in total R\&D spending (Wikipedia \& http:// www.royalsociety.org) and some groups of economies like OECD, high-income, upper middle-income and low- and middle-income countries. The list of top ten countries in descending order in the total R\&D expenditure are USA, China, Japan, Germany, South Korea, India, France, UK, Russia and Brazil. The data on R\&D, patents and growth of per capita GDP have been taken from the World Bank. The data on R\&D are taken as its total spending as percentage of GDP which is termed as R\&D intensity or R\&D ratio. The indicator for patent is the number of patent applications made by residents and non-residents of the countries and groups. The indicator for income is the growth of per capita GDP (PCGDPgrth) where per capita GDP are at constant 2010 values in US dollars. The period of study is 1996-2017, out of which the data for 1996-2015 is available from the source mentioned above. To extend the data, we have extrapolated the data for the years 2016 and 2017 to better understand the time series properties of the two variables.

There are 22-year data points for all the three indicators, R\&D ratio, number of patents and PCGDPgrth which are not sufficient for time series exercise at individual country and group levels because of the low power of the results. We have thus pooled the cross section and time series data to get powerful panel results. As the study covers 14 (10 countries +4 groups) cross sections and 22 time points so it has a balanced panel data of 308 units $(22 \times 14=308)$.

\section{Panel unit roots}

Panel unit root test conquers the low power problem for an individual country and group-specific study and provides results with more power.

For a data set of a variable ' $x$ ' which is 'R\&D ratio, number of patents and PCGD Pgrth' in the present study, $\left(x_{i, t}, i=1,2, \ldots, N\right.$ (here, $\left.N=14\right)$ and $t=1,2, \ldots, T$ (here, $T=22$ ), where $t$ denotes time; let us consider the linear regression model for panel unit root test under the Augmented Dickey-Fuller (ADF)(p) (1979) regression form-viz.,

$$
\Delta x_{i, t}=\left(\rho_{i}-1\right) x_{i, t-1}+\sum_{j=1}^{p} \gamma_{j} \Delta x_{i, t-j}+R_{i, t}^{\prime} \alpha_{i}+u_{i, t},
$$

where $R_{i, t}^{\prime}$ represents the exogenous variables in the model, including any fixed effects or individual trends. The null hypothesis for this model is $\rho_{i}=1$ and the alternative hypothesis is $\rho_{i}<1$. The above equation can be rewritten as 


$$
\begin{gathered}
p \\
\Delta x_{i, t}=\beta_{i} x_{i, t-1}+\sum \gamma_{j} \Delta x_{i, t-j}+R_{i, t}^{\prime} \alpha_{i}+u_{i, t} \\
j=1
\end{gathered}
$$

The null hypothesis for this model is $\beta_{i}=0$ against the alternative hypothesis $\beta_{i}<0$.

There are two approaches of testing panel unit roots. Test techniques for panel unit roots where the coefficients $\left(\beta_{i} s\right)$ are restricted to be homogeneous across all the cross sections of the panel have been presented by Levin and Lin (1993) and Levin, Lin, and Chu (2002), and for the heterogeneous coefficients by Im et al. (1997, Im, Pesaran, \& Shin, 2003), ADF-Fisher chi-square and PP-Fisher chi-square of Maddala and Wu (1999) and Choi (2001). The assumption of homogeneity $\left(\beta_{i} s=\beta\right.$, say) is clearly restrictive and subject to the possible homogeneity bias of the fixed effect estimator.

The Levin and Lin (1993) and Levin et al. (2002) models are captured by the following equation (3), where $\beta_{i} s=\beta$ :

$$
\begin{gathered}
p \\
\Delta x_{i, t}=\beta x_{i, t-1}+\sum \gamma_{j} \Delta x_{i, t-j}+R_{i, t}^{\prime} \alpha+u_{i, t} \\
j=1
\end{gathered}
$$

The test statistics offered by Maddala and Wu (1999), based on the suggestion of Fischer, is of the form

$$
\chi^{2}=-2 \sum_{i=1}^{N}\left(\log p_{i}\right)
$$

(where $i=1,2, \ldots, N$ ). It follows the chi square distribution under the null hypothesis of $p_{i}=0$ for all the ' $i s_{s}$.' The simulation suggests that the Maddala and Wu's Fisher test is more powerful than the others.

\section{Panel cointegration test}

Two sets of tests are usually done for testing cointegrating relationships among the variables in a panel data structure. Pedroni $(1999,2004)$ and Kao (1999) tests are based on Engle and Granger (1987) two-step residual methodology tests, and Fisher test is a combined Johansen test. The present study applies all the three tests. The methodologies are as follows.

The Engle-Granger (1987) cointegration test is based on an examination of the residuals of a spurious regression performed using I (1) variables. If the variables are cointegrated, then the residuals derived from the linear combinations of the variables should be I (0) or first differenced stationary. Pedroni proposes several tests for cointegration that allow for heterogeneous intercepts and trend coefficients across cross sections. Let us consider the following regression with no intercept constant and trends:

$$
x_{i, t}=\beta_{i} y_{i, t}+u_{i, t}
$$

Under the null hypothesis of no cointegration, the estimated residuals $\varepsilon_{i, t}$ will be I (1). The usual approach is to obtain residuals from Eq. (5) and then test whether the derived residuals are I (1) by running the auxiliary regression for each cross section as 


$$
\begin{gathered}
p_{i} \\
\varepsilon_{i, t}=\rho_{i} \varepsilon_{i, t}-1+\Sigma \gamma_{i j} \Delta \varepsilon_{i, t-j}+e_{i, t} \\
j=1
\end{gathered}
$$

The Pedroni panel cointegration test (for null hypothesis of no cointegration, i.e. $\rho_{i}=$ 1) statistic $\boldsymbol{N}_{N, T}$ is constructed from the residuals of Eq. (6). A total of eleven statistics with varying degree of properties (size and power for different $N$ and $T$ ) are generated. Pedroni shows that the standardized statistic, as given below, is asymptotically normally distributed

$$
\left[\boldsymbol{N}_{N, T}-\mu \sqrt{ } N\right] / \sqrt{ } v \Rightarrow N(0,1)
$$

where $\mu$ and $v$ are Monte Carlo-generated adjustment terms.

On the contrary, Kao (1999) presents two tests for cointegration in panel data: the DF and ADF type tests. He considers the special case where cointegration vectors are homogeneous between individuals. Kao considers the model as depicted in Eqs. (5) and (6). In order to test the null hypothesis of no cointegration, the null can be written as: $\mathrm{H}_{0}: \rho=1$ against the alternative $\mathrm{H}_{\mathrm{A}}: \rho<1$. The OLS estimate of $\rho$ is given by

$$
\hat{\rho}=\frac{\sum_{i=1}^{N} \sum_{t=2}^{T} \widehat{\varepsilon}_{i t} \hat{\varepsilon}_{i t-1}}{\sum_{i=1}^{N} \sum_{t=2}^{T} \hat{\varepsilon}^{2}{ }_{i t-1}}
$$

Johansen (1988) proposes two different statistics with different configurations, one of them is the likelihood ratio trace statistics, and the other one is maximum eigen value statistics for that purpose. Taking the Johansen test for cointegration, Maddala and Wu (1999) consider Fisher's (1932) suggestion to combine individual tests, to propose an alternative to the two previous tests, for testing for the cointegration in the full panel by combining individual cross section tests for cointegration. The test statistics is

$$
-2 \sum_{i=1}^{N} \log \left(q_{i}\right) \Rightarrow X_{2 N}^{2},
$$

where ' $q_{i}^{\prime}$ ' is the probability value for testing cointegration for individual cross sections. The test statistic for the panel as stated above will follow chi-square distribution.

\section{Vector error correction mechanism (VECM)}

After confirmation on the existence of the long-run equilibrium relations among the variables, we need to test whether the errors due to the short-run deviations from the equilibrium relations are corrected and the series converge to the longrun relation. Vector error correction mechanism (VECM) captures this fact. VECM is a restricted vector autoregressive (VAR) model which is intended for using with cointegrated non stationary series. The VECM has cointegration relations built into the specification. The cointegration term is known as the error correction term. 
Before, to present the VECM, we need to frame the VAR structure with three variables, PCGDPGrth rate $(G), R \& D$ ratio $(R)$ and number of patents $(P)$. The set of equations are as follows:

$$
\begin{aligned}
& G_{t}=\alpha_{1}+\sum_{j=1}^{n} \beta_{1 j} G_{t-j}+\sum_{j=1}^{n} \gamma_{1 j} R_{t-j}+\sum_{j=1}^{n} \delta_{1 j} P_{t-j}+u_{1 t} \\
& R_{t}=\alpha_{2}+\sum_{j=1}^{n} \beta_{2 j} G_{t-j}+\sum_{j=1}^{n} \gamma_{2 j} R_{t-j}+\sum_{j=1}^{n} \delta_{2 j} P_{t-j}+u_{2 t} \\
& P_{t}=\alpha_{3}+\sum_{j=1}^{n} \beta_{3 j} G_{t-j}+\sum_{j=1}^{n} \gamma_{3 j} R_{t-j}+\sum_{j=1}^{n} \delta_{3 j} P_{t-j}+u_{3 t}
\end{aligned}
$$

where $\alpha_{1}, \beta_{1 j}, \gamma_{1 j}, \delta_{1 j}$ and $\theta_{1 j}$ stand for the intercept and slope coefficients when PCGD PGrth is the dependent variable. The notations with numbers will change accordingly from 2 to 3 for R\&D and number of patents as the dependent variables. Once the optimum lag is selected, then the VAR model will have to be modified. Suppose optimum lag is 3 , then the values of $j$ will be 1,2 and 3 .

To present the VECM, suppose there is a two-variable system with one cointegrating equation and no lagged difference terms. The cointegrating equation for no intercept and trend is given by the following equation:

$$
x_{t}=\beta y_{t}
$$

The estimated error term in the first difference is given as

$$
\varepsilon_{t-1}=x_{t-1}-\beta y_{t-1}
$$

Therefore, the corresponding VEC model is

$$
\begin{aligned}
& \Delta x_{t}=\alpha_{y}\left(x_{t-1}-\beta y_{t-1}\right)+e_{x} \\
& \Delta y_{t}=\alpha_{x}\left(y_{t-1}-\beta x_{t-1}\right)+e_{y}
\end{aligned}
$$

Here, only right-hand-side variables are the error correction (EC) terms which are zero in the long-run equilibrium. However, if ' $y$ ' and ' $x$ ' deviate from the long-run equilibrium, the error correction terms will be nonzero, and each variable adjusts to partially restore the equilibrium relation. The coefficient ' $\alpha$ ' measures the speed of adjustment of the $i$ th endogenous variable towards the equilibrium.

Now, the VECM is set by including the terms $\alpha_{y}\left(x_{t-1}-\beta y_{t-1}\right)$ into Eqs. (10)-(12) as additional explanatory variables on three variables set up and in respective terms. If the error correction terms are found to be negative in sign and statistically significant, then we say that the short-term errors are corrected, and the series are back to the long-run relation. Additionally, we say that there is a long-run causality from ' $y$ ' to ' $x$ ' or vice versa.

Finally, the short-run causality can be tested in this VECM set up by applying the Wald test for coefficient diagnosis.

Suppose it was observed that the three indicators are not cointegrated in gross sense (i.e. satisfied for most of the test statistics), then we could not run VECM, rather stick to the VAR system only (following Eqs. (10)-(12)). In that case, the long-run associations are discarded, and the test for short-run interplays would be done through the 
Granger causality in the VAR set up. The decision rules to VAR causality tests will be as follows.

The short-run causality, say in Eq. (10), from R\&D and patents to PCGDPGrth can be examined on the basis of null hypothesis, $\mathrm{H}_{0}: \gamma_{1 j}=\delta_{1 j}=0$. If the null hypothesis is accepted with probability values less than 0.05 then, there is no causality running from $R \& D$ and patents to PCGDPGrth. The Wald test ensures the results. We can similarly test for the other directions of causality with the changes in the roles of variables.

It is well known that the VAR model is useful in deriving impulse responses of two standard error values upon one variable due to the others and variance decomposition which reflects the proportion of the forecast error variance of a variable due to shocks in itself and others for short- and long-term periods. Hence, it is required to test for the impulse response and variance decomposition.

After all computations are made, the residual diagnostic checking is to be done with the null hypothesis of a normal distribution of the residual series. The Jarque-Bera (J-B) test statistics is capable of testing the normality feature. The test statistics measures the difference of the skewness and kurtosis of the series from the normal distribution. The $\mathrm{J}-\mathrm{B}$ statistics is expressed as follows:

$$
\mathrm{J}-\mathrm{B}=\frac{N}{6}\left(s^{2}+\frac{(k-3)^{2}}{4}\right),
$$

where ' $s$ ' is the skewness and ' $k$ ' is the kurtosis. Under the null hypothesis of a normal distribution, the J-B statistic is distributed as chi square with 2 degrees of freedom. The reported probability is the probability that a J-B statistic exceeds (in absolute value) the observed value under the null hypothesis. If the probability value is small, then there will be rejection of the null hypothesis of a normal distribution.

\section{Analysis of results and discussions}

Before entering into rigorous econometric exercises, let us have a look on the descriptive statistics of all the three concerned variables, $R \& D$ share, number of patents and PCGDP growth rates (Table 1). It is observed from the table that, on an average, Japan spends 3.11\% of her GDP upon R\&D activities followed by South Korea (3.08\%) and USA (2.63\%), and India is the lowest spender (mere $0.77 \%$ ) upon the head preceded by Brazil and Russia. The high-income countries as a group usually spends more of their GDP on average compared to other group of countries taken for the study. With respect to the average number of patents over the study period, USA leads the countries followed by China and Japan, and France is at the bottom of the list, even below India. The high-income countries, on the other hand, have higher average number of patents compared with all the remaining groups of countries. Finally, the average growth rate of per capita GDP is highest for China (8.39\%) followed by India (5.43\%) and South Korea. With respect to the groups, the average income growth is highest for upper middle-income followed by the low- and middle-income groups.

The maximum share of R\&D has been done by South Korea and minimum of the same by India. For the number of patents, the maximum number has been obtained by China and the minimum by Brazil. Finally, the maximum income growth rate has been obtained by China and the minimum by Russia. But maximum variation over time (as 


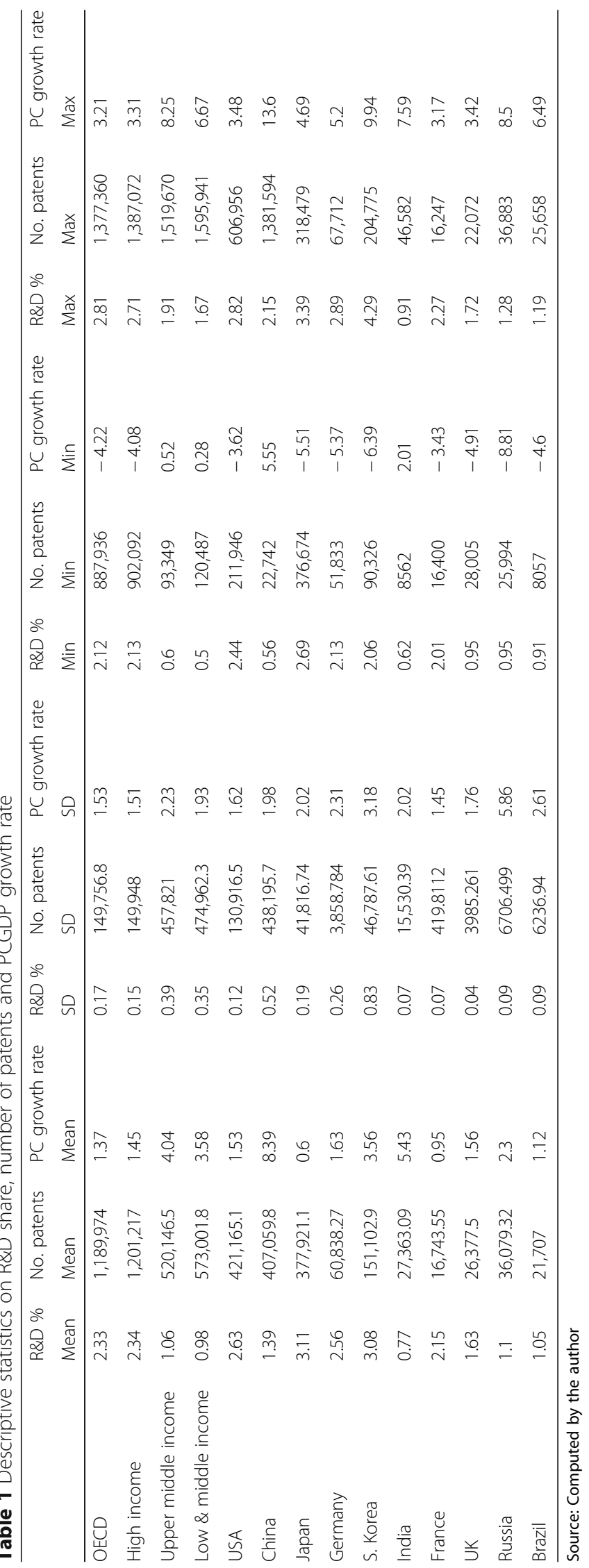


measured by standard deviation) of R\&D share is by South Korea and minimum by the UK. For the number of patents, the maximum dispersion is observed for China and the minimum for France. Finally, the maximum variation in income growth rate is observed for South Korea and the minimum for the UK.

\section{Panel unit root test results}

The series for R\&D ratio, number of patents and PCGDPGrth of the panel are found to be non stationary at their levels (values not shown). It is hence investigated whether the first differences of the three series in panel form are stationary. The estimated results using Eqs. (1)-(4) are presented in Table 2.

It is observed that all the series in first differenced form are stationary under all the tests of common and individual unit root processes. Hence, testing for cointegration among the three series will not be a barrier. We proceed for the test in the following section.

\section{Panel cointegration test results}

The results of panel cointegration tests along three lines, Pedroni, Kao and JohansenFisher, are now presented and analyzed. Table 3 depicts the Pedroni test results under three specifications as mentioned.

It is observed, except in a few occasions, that there are no significant cointegrating results in all the three specifications since the estimated test statistics take too low values and high probability values to accept the null hypothesis of no cointegration.

Now, we attempt for the second test which is Kao test. The results are shown Table 4. It shows that the residual of the regression of panel data constituting three variables, one being dependent among them, is stationary at level as the probability value of the $\mathrm{ADF}$ is at par the desired value of 0.05 . This means that the Kao test, R\&D ratio, patents and income growth rate are in long-run equilibrium relations.

Lastly, the results of Fisher-Johansen test, as presented in Table 5, show that there is no cointegrating relation among the three variables across the panel of the countries

Table 2 Panel unit root test results for R\&D share, number of patents and PCGDP growth rate

\begin{tabular}{|c|c|c|c|c|c|c|c|}
\hline \multirow[t]{2}{*}{ Method } & \multirow[t]{2}{*}{ Null hypothesis } & \multicolumn{3}{|c|}{ Test statistics with intercept (prob.) } & \multicolumn{3}{|c|}{ Test statistics with intercept \& trend (prob.) } \\
\hline & & $R \& D$ & Patent & PCGDPGrth & $R \& D$ & Patent & PCGDPGrth \\
\hline $\begin{array}{l}\text { Levin, Lin } \\
\text { and Chu }\end{array}$ & $\begin{array}{l}\text { Unit root (under } \\
\text { common unit } \\
\text { root process) }\end{array}$ & $-4.845(0.00)$ & $-4.235(0.00)$ & $-14.94(0.00)$ & $-4.433(0.00)$ & $-4.40(0.00)$ & $-13.82(0.00)$ \\
\hline $\begin{array}{l}\text { Bruitang } t \\
\text { test }\end{array}$ & $\begin{array}{l}\text { Unit root (under } \\
\text { common unit } \\
\text { root process) }\end{array}$ & - & - & - & $-4.35(0.00)$ & $-4.58(0.00)$ & $-10.92(0.00)$ \\
\hline $\begin{array}{l}\text { Im, Pesaran } \\
\text { and Shin }\end{array}$ & $\begin{array}{l}\text { Unit root (under } \\
\text { individual unit } \\
\text { root process) }\end{array}$ & $-4.81(0.00)$ & $-4.279(0.00)$ & $-13.50(0.00)$ & $-3.811(0.00)$ & $-3.90(0.00)$ & $-12.35(0.00)$ \\
\hline $\begin{array}{l}\text { MW-ADF- } \\
\text { Fisher } \\
\text { chi-square }\end{array}$ & $\begin{array}{l}\text { Unit root (under } \\
\text { individual unit } \\
\text { root process) }\end{array}$ & $74.39(0.00)$ & $70.256(0.00)$ & $198.92(0.00)$ & $60.245(0.00)$ & $62.31(0.00)$ & $164.24(0.00)$ \\
\hline $\begin{array}{l}\text { MW-PP_- } \\
\text { Fisher } \\
\text { chi-square }\end{array}$ & $\begin{array}{l}\text { Unit root (under } \\
\text { individual unit } \\
\text { root process) }\end{array}$ & $150.02(0.00)$ & $105.80(0.00)$ & $1051.12(0.00)$ & $158.86(0.00)$ & $95.97(0.00)$ & $965.24(0.00)$ \\
\hline
\end{tabular}

Note: Automatic lag length selection is based on AIC: 1 to 4. Probabilities for Fisher tests (source: computed by the authors using Eviews) 
Table 3 Pedroni residual panel cointegration test for inflation and CC series

\begin{tabular}{|c|c|c|c|c|}
\hline $\begin{array}{l}\text { Hypotheses } \rightarrow / \\
\text { test criteria } \downarrow\end{array}$ & $\begin{array}{l}\text { Null hypothesis: no } \\
\text { cointegration }\end{array}$ & & Statistic (prob.) & $\begin{array}{l}\text { Weighted statistic } \\
\text { (prob.) }\end{array}$ \\
\hline \multirow[t]{7}{*}{ No deterministic trend } & \multirow{4}{*}{$\begin{array}{l}\text { Alternative hypothesis: } \\
\text { common AR coefficients } \\
\text { (within-dimension) }\end{array}$} & Panel v-statistic & $0.183(0.42)$ & $-1.05(0.83)$ \\
\hline & & Panel rho-statistic & $0.21(0.51)$ & $1.16(0.87)$ \\
\hline & & Panel PP-statistic & $-0.72(0.23)$ & $0.36(0.64)$ \\
\hline & & Panel ADF-statistic & $-0.97(0.16)$ & $0.16(0.56)$ \\
\hline & \multirow{3}{*}{$\begin{array}{l}\text { Alternative hypothesis: } \\
\text { individual AR coefficients } \\
\text { (between-dimension) }\end{array}$} & Group rho-statistic & $2.189(0.93)$ & - \\
\hline & & Group PP-statistic & $0.65(0.74)$ & - \\
\hline & & Group ADF-statistic & $0.32(0.62)$ & - \\
\hline \multirow{7}{*}{$\begin{array}{l}\text { Deterministic intercept } \\
\text { and trend }\end{array}$} & \multirow{4}{*}{$\begin{array}{l}\text { Alternative hypothesis: } \\
\text { common AR coefficients } \\
\text { (within-dimension) }\end{array}$} & Panel v-statistic & $1.506(0.06)$ & $1.03(0.15)$ \\
\hline & & Panel rho-statistic & $-0.81(0.20)$ & $1.05(0.85)$ \\
\hline & & Panel PP-statistic & $-4.90(0.00)$ & $-1.09(0.13)$ \\
\hline & & Panel ADF-statistic & $-1.89(0.02)$ & $-0.49(0.30)$ \\
\hline & \multirow{3}{*}{$\begin{array}{l}\text { Alternative hypothesis: } \\
\text { individual AR coefficients } \\
\text { (between-dimension) }\end{array}$} & Group rho-statistic & $2.12(0.95)$ & - \\
\hline & & Group PP-statistic & $-0.38(0.35)$ & - \\
\hline & & Group ADF-statistic & $-0.75(0.22)$ & - \\
\hline \multirow{7}{*}{$\begin{array}{l}\text { No deterministic } \\
\text { intercept and trend }\end{array}$} & \multirow{4}{*}{$\begin{array}{l}\text { Alternative hypothesis: } \\
\text { common AR coefficients } \\
\text { (within-dimension) }\end{array}$} & Panel v-statistic & $-0.41(0.66)$ & $-1.22(0.88)$ \\
\hline & & Panel rho-statistic & $-0.60(0.27)$ & $0.92(0.82)$ \\
\hline & & Panel PP-statistic & $-1.64(0.05)$ & $0.22(0.58)$ \\
\hline & & Panel ADF-statistic & $-1.08(0.13)$ & $0.78(0.78)$ \\
\hline & \multirow{3}{*}{$\begin{array}{l}\text { Alternative hypothesis: } \\
\text { individual AR coefficients } \\
\text { (between-dimension) }\end{array}$} & Group rho-statistic & $2.66(0.99)$ & - \\
\hline & & Group PP-statistic & $1.15(0.87)$ & - \\
\hline & & Group ADF-statistic & $1.71(0.95)$ & - \\
\hline
\end{tabular}

Source: computed by the authors using Eviews

since both the trace test and max-eigen value statistics produce insignificant results in statistical terms.

Combining all the three results of cointegration (Tables 3, 4 and 5), we come to the point that in the overall sense, the three series, $R \& D$, patents and growth rate, have no long-run associations.

\section{VECM and VAR test results}

Since the selected three variables are found not being at the equilibrium relation as there was no cointegrating relations among them, no question of error correction, thus, arises. Therefore, we shift our point of attention from long-run to short-run interplays among the three variables. The optimum lag is derived to 2, where most of the measuring sticks take lower values. We first estimate the coefficients of the VAR set up (Eqs. (10)-(12)) after converting the variables from their levels to first differences. The results are presented in Table 6 . Column 1 presents the list of lagged independent

Table 4 Kao residual cointegration test

\begin{tabular}{lll}
\hline Null hypothesis: no cointegration & $t$ statistic & Prob. \\
\hline ADF & 1.61 & 0.05 \\
\hline
\end{tabular}

Source: Computed by the authors using Eviews 
Table 5 Fisher Johansen cointegration test

\begin{tabular}{lllll}
\hline & $\begin{array}{l}\text { Fisher Stat. } \\
\text { (from trace test) }\end{array}$ & Prob. & $\begin{array}{l}\text { Fisher stat. } \\
\text { (from max-eigen test) }\end{array}$ & Prob. \\
\hline None & 76.03 & 0.000 & 71.3 & 0.000 \\
At most 1 & 27.4 & 0.48 & 25.19 & 0.61 \\
At most 2 & 34.29 & 0.19 & 34.29 & 0.09 \\
\hline
\end{tabular}

Source: computed by the authors using Eviews

variables and columns 2 to 4 cover the list of first differenced dependent variables. Columns 2, 3 and 4 respectively represent Eqs. (10)-(12).

It is observed from the results that the change of PCGDPGrth in the current period is not significantly influenced by the changes in $R \& D$ share and number of patents in both the past periods but significantly by the two past values of the changes in PCGD PGrth. The similar types of conclusions are also obtained for changes in the number of patents acting as dependent variable (column 3). But there are differences in the results when $R \& D$ share acts as a dependent variable. The changes in $R \& D$ share in the

Table 6 VAR estimated results

\begin{tabular}{|c|c|c|c|}
\hline \multirow{3}{*}{ (1) } & \multicolumn{3}{|c|}{ Included observations: 266 after adjustments, $t$ statistics are in [ ] } \\
\hline & $(2)$ & (3) & (4) \\
\hline & $\mathrm{D}(\mathrm{PCGDPGRTH})$ & D(RDSHARE) & D(PATENT) \\
\hline \multirow[t]{2}{*}{ D(RDSHARE(-1)) } & -3.01791 & 0.268968 & 37959.42 \\
\hline & {$[-1.21524]$} & [4.50756] & {$[1.25761]$} \\
\hline \multirow[t]{2}{*}{$\mathrm{D}(\mathrm{RDSHARE}(-2))$} & 0.348717 & 0.180843 & -5398.25 \\
\hline & {$[0.13739]$} & [2.96527] & {$[-0.17499]$} \\
\hline \multirow[t]{2}{*}{ D(PATENT(-1)) } & $-5.97 \mathrm{E}-06$ & $1.96 \mathrm{E}-07$ & 0.535536 \\
\hline & {$[-0.92276]$} & {$[1.26268]$} & [6.81089] \\
\hline \multirow[t]{2}{*}{ D(PATENT(-2)) } & $-2.50 \mathrm{E}-06$ & $6.62 \mathrm{E}-08$ & 0.265961 \\
\hline & {$[-0.32431]$} & {$[0.35717]$} & {$[2.83766]$} \\
\hline \multirow[t]{2}{*}{$\mathrm{D}(\mathrm{PCGDPGRTH}(-1))$} & -0.50584 & 0.005315 & 884.6956 \\
\hline & {$[-8.58711]$} & [3.75547] & {$[1.23567]$} \\
\hline \multirow[t]{2}{*}{$\mathrm{D}(\mathrm{PCGDPGRTH}(-2))$} & -0.32927 & 0.005604 & -417.358 \\
\hline & {$[-5.74055]$} & [4.06651] & {$[-0.59866]$} \\
\hline \multirow[t]{2}{*}{ C } & 0.226961 & 0.016377 & 3694.233 \\
\hline & {$[1.21645]$} & [3.65309] & {$[1.62907]$} \\
\hline R-squared & 0.27056 & 0.224309 & 0.553938 \\
\hline Adj. R-squared & 0.253662 & 0.20634 & 0.543605 \\
\hline Sum sq. resids & 1573.825 & 0.908623 & $2.32 E+11$ \\
\hline S.E. equation & 2.465065 & 0.05923 & $29,961.02$ \\
\hline F statistic & 16.01119 & 12.48265 & 53.60617 \\
\hline Log likelihood & -613.881 & 377.9121 & -3115.73 \\
\hline Akaike AIC & 4.668277 & -2.78881 & 23.47915 \\
\hline Schwarz SC & 4.762579 & -2.69451 & 23.57345 \\
\hline Mean dependent & 0.027685 & 0.035921 & $20,700.14$ \\
\hline SD dependent & 2.853387 & 0.066485 & $44,349.22$ \\
\hline
\end{tabular}

Note: Optimum lag has been derived as 2 . The bold figures indicate statistically significant results Source: computed by the authors using Eviews 
current period not only get influenced by the past values of it but also positively and significantly by the changes in the PCGDPGrth rates of the two lagged values. More specifically, $1 \%$ increase in the per capita growth rate of income of the one and two periods' lags leads to increase in the rate of $R \& D$ share of the current period by $0.053 \%$ and $0.056 \%$ respectively.

Let us explore the causal interplays among the three series as part of the short-run analysis. The panel causality test is done in line with Granger (1969), and the results are given in Table 7. The null hypotheses in all the cases refer to the instance that there are no causal effects from any of the two or all variables into any one. We have thus three sets of test results. The optimum lag is again derived as 2 .

From the results, it is observed that there are strong significant causality running from the number of patents, PCGDPGrth, and all of the three to the current value of $R \& D$ share which means high-income growth rates and number of patents seeking the influence of the R\&D activity. There are weak causal relations from $R \& D$ share and patents to income growth rate. Finally, neither patent nor R\&D make a cause to income growth rates.

\section{Impulse responses and variance decompositions}

The graphs of impulse responses (IR) and the table for variance decompositions (VD) are presented in the Appendix. It is observed from the IR graphs that R\&D share has been positive due to the impulses from number of patents and PCGD PGrth rates. Further, PCGDPGrth has been mostly negative due to R\&D share and patents. But patents' impulses due to R\&D and income growth are not much; it hovers around zero values. Further, the results of VD show that variances of $R \& D$ share is more due to the shock by itself, and in the long run, the shocks of

Table 7 VAR Granger causality/block exogeneity Wald tests

\begin{tabular}{llll}
\hline & \multicolumn{3}{l}{ Included observations: 266} \\
\cline { 2 - 4 } Dependent variable: D(PCGDPGRTH) & Chi-sq & df & Prob. \\
\hline Excluded & 1.523615 & 2 & 0.4668 \\
D(RDSHARE) & 4.859931 & 2 & 0.088 \\
D(PATENT) & 7.926856 & 4 & 0.0943 \\
All & & & \\
Dependent variable: D(RDSHARE) & Chi-sq & df & Prob. \\
Excluded & 8.258505 & 2 & 0.0161 \\
D(PATENT) & 22.08857 & 2 & 0 \\
D(PCGDPGRTH) & 34.10394 & 4 & 0 \\
All & & & \\
Dependent variable: D(PATENT) & Chi-sq & df & \\
Excluded & 1.617572 & 2 & 0.4454 \\
D(RDSHARE) & 2.903713 & 2 & 0.2341 \\
D(PCGDPGRTH) & 3.839845 & 4 & 0.4281 \\
All & & &
\end{tabular}

Note: Optimum lag has been derived as 2 Source: computed by the authors using Eviews 
patents and income growth become significantly rising. The variances of income growth are mostly by itself over the longer periods but in a stable form over short and long terms by patents and R\&D share. The same is for the variances of patents since $95 \%$ of its variances are due to itself and not by other two.

The estimated results of VAR are robust as it is stable since all the inverse roots of the AR polynomial lie within the unit circle (graph is in the Appendix) in the one hand, and on the other hand, they satisfy the VAR residual normality tests (Table 8 ) in line with Jarque-Bera. The probability values are well below 5\% level of significance to reject the null hypotheses that residuals are multivariate normal.

Hence, it is inferred that huge expenses on R\&D and generating patent rights do not have influential impacts upon the income growth of the countries so far as the panel of countries and groups of economies are concerned. Although, there have been long-run associations between $R \& D$ share and income levels and growths of some countries as explored by Das and Mukherjee (2019) for the same period, the present study does not find such evidence at the panel data format. This means that whatever is significantly observed in particular countries may not happen so for the aggregated pooled data. There have been thus unnecessary growths of market imperfections in the R\&D head which generates social cost or dead weight loss. The funds could have been used in different income-generating economic, social and environmental activities to ensure sustained development of the individual as well as groups of nations.

\section{Discussions}

There have been debates in the existing literature on whether spending on research and developmental activity at all influence the growth of a nation. Some studies report in its favour and others do not. There have been increasing trends in the spending in the R\&D head across the countries, especially by the so-called developed and highly emerging nations. Having an endogenous growth augmenting the role spending in $R \& D$ head should enhance economic growths if free spillovers and conversion of new innovations to products' supply are concerned. But in reality, what happens is that the countries in the leading list of $R \& D$ spending mostly use these innovating outputs in obtaining patents and preserving it for high royalty earning. This is one sort of social cost as mentioned in different studies. Therefore, the actual benefit of $R \& D$ goes for profit earning, not to income-generating activities. The present study, based on the panel of leading income groups and countries, has arrived at the similar conclusions. The novelty of the study is that it covered the panel of groups of economies as well as the

Table $8 \mathrm{VAR}$ residual normality tests

\begin{tabular}{llll}
\hline Component & Jarque-Bera & df & Prob. \\
\hline 1 & 28.45733 & 2 & 0 \\
2 & 657.1518 & 2 & 0 \\
3 & 342.2808 & 2 & 0 \\
Joint & 1027.89 & 6 & 0 \\
\hline
\end{tabular}

Source: computed by the authors using Eviews 
leading economies in the $R \& D$ head. Hence, to have a fruitful social benefit of such a huge fund for $R \& D$, that are taken away from other economic activities, the policymakers in the countries in particular, and world in general, should intervene into the unfair activity and ensure increasing growth rates by taking the funds from such activity and/or allowing the research outputs to be used in favour of utility-generating activities.

\section{Comparing the results with the existing studies}

The derived results from the panel of countries show that there has been no long-run association among $R \& D$ spending, number of patents and income growth per capita, but there are short-run causal interplays from the number of patents and income growth to $R \& D$ share which means the primary objective of $R \& D$ expenditure is to obtain patents rights of the invented intellectual properties. Although the existing studies' sample observations are different to that of the present study, we can make comparison with the main directions of results. The results of the present study mostly agree with the observations of Nordhaus (1969), Aghion and Howitt (1992), Levin et al. (1997), and Das and Mukherjee (2019), among others, where excessive and directionless R\&D spending may generate social costs, but disagree with the observations of Kwack and Lee (2006), Kuo and Yang (2008), Gulmez and Yardımciog ${ }^{` l u}$ (2012), Gocer (2013), and Gumus and Celikay (2015), among others, where it worked in favour of the growth-augmenting activities.

\section{Conclusion and policy recommendations}

The study is now in a position to wrap up. The selected three variables-R\&D share, number of patents and per capita income growth-in the panel of countries and groups do not establish any long-run associations among them. The short-run relationships among them show that per capita income growth positively affects $R \& D$ share but $R \& D$ does not affect the number of patents. Again, the number of patents does not affect income growth rates. Further, the shortrun interplays among the three shows that the number of patents and PCGD PGrth make significant cause to $R \& D$ share which means the primary objective of $R \& D$ expenditure is to obtain patent rights of the invented intellectual properties. The impulse response functions show that $R \& D$ share has been positive due to the impulses from the number of patents and PCGDPGrth rates. Further, the results of variance decompositions show that variances of $R \& D$ share is more due to the shock by itself, and in the long run, the shocks of patents and income growth become significantly rising.

It is thus inferred that huge expenses on R\&D and generating patent rights lead to unnecessary growth of market imperfections in the R\&D head which generates social cost or dead weight loss. It is hence recommended that a part of the funds for R\&D could have been used in different income-generating economic, social and environmental activities to ensure sustained development of the individual as well as groups of nations. 


\section{Appendix}
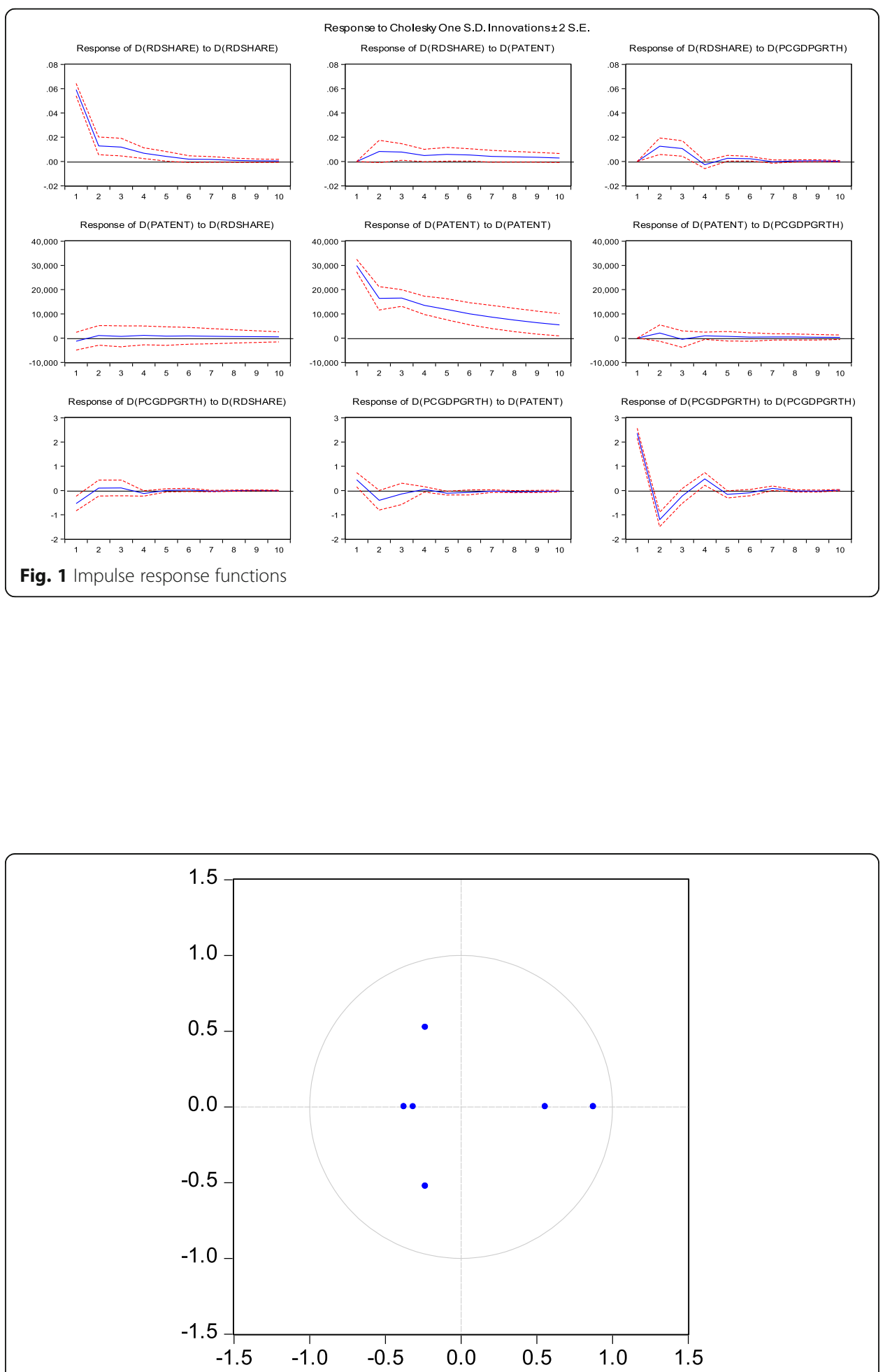

Fig. 2 Inverse roots of AR characteristic polynomial 
Table 9 Variance decompositions

\begin{tabular}{|c|c|c|c|c|c|}
\hline & Period & S.E. & D(RDSHARE) & $\mathrm{D}(\mathrm{PCGDPGRTH})$ & D(PATENT) \\
\hline \multirow[t]{10}{*}{ Variance decomposition of D(RDSHARE) } & 1 & 0.059187 & 100 & 0 & 0 \\
\hline & 2 & 0.062459 & 94.01775 & 4.888333 & 1.093919 \\
\hline & 3 & 0.064861 & 90.4759 & 7.885775 & 1.638325 \\
\hline & 4 & 0.065457 & 89.89587 & 7.823029 & 2.281101 \\
\hline & 5 & 0.065894 & 89.09499 & 8.021917 & 2.883096 \\
\hline & 6 & 0.066173 & 88.42402 & 8.182175 & 3.393807 \\
\hline & 7 & 0.066329 & 88.06616 & 8.151538 & 3.782303 \\
\hline & 8 & 0.066456 & 87.74824 & 8.149495 & 4.102269 \\
\hline & 9 & 0.066557 & 87.48979 & 8.159912 & 4.3503 \\
\hline & 10 & 0.066628 & 87.30769 & 8.152066 & 4.540246 \\
\hline \multirow[t]{10}{*}{ Variance Decomposition of D(PCGDPGRTH) } & 1 & 2.465358 & 4.73263 & 95.26737 & 0 \\
\hline & 2 & 2.771294 & 3.873821 & 95.67596 & 0.450219 \\
\hline & 3 & 2.785086 & 3.978012 & 95.50449 & 0.5175 \\
\hline & 4 & 2.828958 & 4.042071 & 95.4276 & 0.530324 \\
\hline & 5 & 2.835665 & 4.023121 & 95.36775 & 0.609132 \\
\hline & 6 & 2.838288 & 4.021735 & 95.32755 & 0.650714 \\
\hline & 7 & 2.839939 & 4.023632 & 95.30156 & 0.674813 \\
\hline & 8 & 2.840443 & 4.022626 & 95.27609 & 0.70128 \\
\hline & 9 & 2.84092 & 4.021376 & 95.25819 & 0.720434 \\
\hline & 10 & 2.841127 & 4.021188 & 95.24515 & 0.733658 \\
\hline \multirow[t]{10}{*}{ Variance Decomposition of D(PATENT) } & 1 & 29256.21 & 0.191695 & 2.74788 & 97.06043 \\
\hline & 2 & 33133.24 & 0.243246 & 4.35231 & 95.40444 \\
\hline & 3 & 37096.5 & 0.212724 & 3.941859 & 95.84542 \\
\hline & 4 & 39492.22 & 0.253504 & 4.178638 & 95.56786 \\
\hline & 5 & 41360.94 & 0.259705 & 4.298927 & 95.44137 \\
\hline & 6 & 42679.53 & 0.28115 & 4.333575 & 95.38528 \\
\hline & 7 & 43680.96 & 0.294265 & 4.373416 & 95.33232 \\
\hline & 8 & 44430.95 & 0.304606 & 4.413838 & 95.28156 \\
\hline & 9 & 44995.79 & 0.312848 & 4.434131 & 95.25302 \\
\hline & 10 & 45423.92 & 0.319278 & 4.450963 & 95.22976 \\
\hline
\end{tabular}

Cholesky ordering: D(RDSHARE) D(PCGDPGRTH) D(PATENT)

\section{Abbreviations}

R\&D: Research and development; VAR: Vector autoregression; IP: Intellectual property; EU: European Union; OECD: Organization of Economic Cooperation and Development; GDP: Gross domestic product; USA: United States of America; UK: United Kingdom; GMM: Generalized method of moments; PCGDPgrth: Growth of per capita GDP; DF: Dickey-Fuller; ADF: Augmented Dickey-Fuller; VECM: Vector error correction mechanism; J-B: Jarque-Bera; IR: Impulse response; VD: Variance decomposition

\section{Acknowledgements}

The author deeply acknowledges the cooperation of the Springer Waiver Resolution Team who made waiving of the APC at full extent as the author had no funding agency to pay for the APC.

\section{Author's contributions}

The results obtained from the current research is solely derived and articulated by the author himself. It is further justified by the presence of a single author in the study. The author read and approved the final manuscript.

Funding

The author declares that he has no funding agency behind the preparation of the manuscript, and he had thus opted for full waiver of APC. 


\section{Availability of data and materials}

The author has used the open data on the listed variables, growth of income, number of patents and R\&D, published by the World Bank (http://www.worldbank.org). The study has not used data of any third party.

\section{Ethics approval and consent to participate}

The present manuscript abides by all the publication ethics. In its preparation, it did not involve any human participants, human material, or human data, and thus it did not violate the Helsinki Declaration. Hence, the question of consent to participate does not arise.

\section{Consent for publication}

The author hereby gives his full consent to the JIAE off Springer to publish the article.

\section{Competing interests}

The author, in preparing the manuscript, has no conflict of interests with others in financial and non-financial matters. It did not use funding by any third party, not used any part of researches of others without citing and did not use any animal contribution into the study.

Received: 5 June 2020 Accepted: 17 August 2020

Published online: 14 September 2020

\section{References}

Aghion, P., \& Howitt, P. (1992). A model of growth through creative destruction. Econometrica, 60(2), 323-351.

Almeida, A. \& Teixeira, A. C. (2007). Does patenting negatively impact on R\&D investment? An international panel data assessment. FEP Working Papers, 255, Universidade do Porto, Faculdade de Economia do Porto

Altuzarra, A. (2019). R\&D and patents: Is it a two way street? Economics of Innovation and New Technology, 28(2), $180-196$. https://doi.org/10.1080/10438599.2018.1449726.

Ballot, G., Fakhfakh, F. \& Taymaz, E. (2001). Who benefits from training and R\&D? The firm or the workers? A study on panels of French and Swedish firms. mimeo

Barro, R. J. (1991). Economic growth in a cross-section of countries. Quarterly Journal of Economics, 106(2), 407-443.

Blackburn, K., Huang, V. T. Y., \& Pozzolo, A. F. (2000). Research, development and human capital accumulation. Journal of Monetary Economics, 22, 189-206.

Blanco, L., Prieger, J. \& Gu, J. (2013). The Impact of Research and Development on Economic Growth and Productivity in the US States, Pepperdine University, School of Public Policy Working Papers, November, No 48, http://digitalcommons. pepperdine.edu/sppworkingpapers/48.

Boldrin, M., \& Levine, D. K. (2013). The case against patents. Journal of Economic Perspectives, 27(1), 3-22.

Bozkurt, C. (2015). R\&D expenditures and economic growth relationship in Turkey. International Journal of Economics and Financial Issues, 5(1), 188

Chen, Q. (2015). The effect of patent laws on economic growth: evidence from cross-country panels during 1600-1913 Intel Prop Rights. 3: 145, doi:https://doi.org/10.4172/2375-4516.1000145

Choi, C. \& Yi, M. H. (2018). "The Internet, R\&D expenditure and economic growth," Applied Economics Letters, 25(4), $328-335$.

Choi, I. (2001). Unit Root Tests for Panel Data. Journal of International Money and Finance, 20, 249-272.

Chou, Y. K. (2002). The Australian Growth Experience (1960-2000), R \& D based, Human Capital-Based or Just Steady State Growth? Research Paper No. 855, ISSN 0819-2642, Department of Economics, University of Melbourne. http:// econpapers.repec.org/RePEc:mlb:wpaper:855.

Danguy, J., de Rassenfosse, G., \& van Pottelsberghe de la Potterie, B. (2009). The R\&D-patent relationship: an industry perspective. EIB Papers, European Investment Bank (EIB). Luxembourg, 14(1), 170-195.

Das, R. C. \& Mukherjee, S. (2019). Do spending on R\&D influence income? An enquiry on world's leading economies and groups, Journal of the Knowledge Economy, Springer Nature, May, doi.org/10.1007/s13132-019-00609-0

Engle, R. F., \& Granger, C. W. (1987). Co-integration and error correction: representation, estimation and testing. Econometrica, 55

Falk, M. (2007). R\&D spending in the high-tech sector and economic growth, Research in Economics, 61, $140-147$.

Freimane R. \& Bāliņa S. (2016). "Research and Development Expenditures and Economic Growth in the EU: A Panel Data Analysis," Economics and Business, Sciendo, 29(1), pages 5-11, August.

Gocer, I. (2013). Effects of R\&D expenditures on high technology exports, balance of foreign trade and economic growth. Maliye Dergisi, 165, 215-240.

Granger, C. W. J. (1969). Investigating causal relations by econometric models and cross spectral methods. Econometrica, 37(3), 424.

Grossman, G. M., \& Helpman, E. (1991). Innovation and growth in the economy. Cambridge, MA: MIT Press.

Grossmann, V. (2007). How to promote R\&D-based growth? Public education expenditure on scientists and engineers versus R\&D subsidies. Journal of Macroeconomics, 29, 891-911.

Gulmez, A., \& Yardımcıog 4 lu, F. (2012). The relationship between R\&D expenditures and economic growth in OECD countries: panel cointegration and panel causality analyses (1990-2010). Maliye Dergisi, 163, 335-353.

Gumus, E., \& Celikay, F. (2015). R\&D expenditure and economic growth: new empirical evidence. Margin-The Journal of Applied Economic Research, 9(3), 205-217.

Hall, B. H. (2007). "Patents and patent policy", Oxford Review of Economic Policy, Vol. 23 No. 4. Winter, 2007, 568-587.

Heller, M., \& Eisenberg, R. (1998). Can patents deter innovation? The anticommons in biomedical research. Science, 280(5364), 698-701.

Hu, Albert G.Z., and Adam B. Jaffe, (2007). "IPR, innovation, economic growth and development", Department of Economics, National University of Singapore, October

Im, K.S., Pesaran, M. H., \& Shin, Y. (1997). Testing for Unit Roots in Heterogeneous Panels. Mimeo Johansen, S. (1988). Statistical analysis of cointegration vectors, Journal of Economic Dynamics and Control, 12(2-3), 231-254. 
Im, K. S., Pesaran, M. H., \& Shin, Y. (2003). Testing for unit roots in heterogeneous panels. Journal of Econometrics, 115, 53-74. Inekwe, J. (2014). The Contribution of R\&D Expenditure to Economic Growth in Developing Economies, Social Indicators Research, 124(3), 727-745.

Jaffe, A. B. \& Lerner, J. (2004). Innovation and its discontents: how our broken patent system is endangering innovation and progress, and what to do about it. Princeton University Press, Princeton, NJ.

Johansen, S. (1988). Statistical analysis of cointegration vectors, Journal of Economic Dynamics and Control, 12(2- 3), 231 254.

Kao, C. (1999). Spurious regression and residual-based tests for cointegration in panel data. Journal of Econometrics, 90, 1-44.

Khan, J.,\& Khattak, N.U.R. (2013).The significance of research and development for economic growth: the case of Pakistan. City University Research Journal 175-86. http://www.cityuniversity.edu.pk/curj/Journals/Journal/July\%202013/Article\%203.pdf.

Kuo, C. C., \& Yang, C. H. (2008). Knowledge capital and spillover on regional economic growth: evidence from China. China Economic Review, 19, 594-604.

Kwack, S. U., \& Lee, Y. S. (2006). Analyzing the Korea's growth experience: the application of R\&D and human capital based growth models with demography. Journal of Asian Economics, 17, 818-831.

Lee, J. W. (2005). Human capital and productivity for Korea's sustained economic growth. Journal of Asian Economics, 16, 663.

Levin, R. C., Klevorick, A. K., Nelson, R. R., \& Winter, S. G. (1997). Appropriating the returns from industrial research and development. Brookings Papers on Economic Activity, 1987(3), 783-831.

Levin, A. and C.F. Lin (1993). Unit Root Tests in Panel Data: New Results. UC San Diego Working Paper 93-56.

Levin, A., Lin, C. F., \& Chu, C. S. J. (2002). Unit root tests in panel data: asymptotic and finite-sample properties. Journal of Econometrics, 108, 1-24.

Lucas, R. (1988). On the mechanics of economic development. Journal of Monetary Economics, 22, 3-42.

Maddala, G. S., \& Wu, S. (1999). A comparative study of unit root tests with panel data and a new simple test. Oxford Bulletin of Economics and Statistics, 61, 631-652.

Nordhaus, W. (1969). An economic theory of technological change. American Economic Review, 59(2), 18-28.

Otomo, P. (2017). The impact of patents on research \& development expenditure as a percentage of gross domestic products: a case in the U.S. and EU economies, Economics Student Theses and Capstone Projects, 55. http:// creativematter.skidmore.edu/econ_studt_schol/55

Pedroni, P. (1999). Critical values for cointegration tests in heterogeneous panels with multiple regressors. Oxford Bulletin of Economics and Statistics, 61, 653-670.

Pedroni, P. (2004). Panel cointegration: asymptotic and finite sample properties of pooled time series tests with an application to the PPP hypothesis. Econometric Theory, 20, 597-625.

Romer, P. M. (1990). Endogenous technological change. Journal of Political Economy, 98(5), 71-101.

Samimi, A. J., \& Alerasoul, S. M. (2009). R\&D and economic growth: new evidence from some developing countries. Australian Journal of Basic and Applied Sciences, 3(4), 3464-3469.

Sierotowicz, T. (2015). Patent activity as an effect of the research and development of the business enterprise sectors in the countries of the European Union. Journal of International Studies, 8(2), 101-113.

Sharma, C. (2012). R\&D and firm performance: evidence from the Indian pharmaceutical industry, Journal of the Asia Pacific Economy, 17(2), 332-42.

Solow, R. M. (1956). A contribution to the theory of economic growth. The Quarterly Journal of Economics, 70(1), 65-94.

Swan, T. W. (1956). Economic growth and capital accumulation. The Economic Record, 32(63), 334-361.

Williams, H. L. (2017). How do patents affect research investments? Annual Review of Economics, 9, 441-469.

Wu, Y. (2010). Innovation and Economic Growth in China, Nedlands, W.A.: University of Western Australia, Business School, Economics working paper No.10-10

\section{Publisher's Note}

Springer Nature remains neutral with regard to jurisdictional claims in published maps and institutional affiliations.

\section{Submit your manuscript to a SpringerOpen ${ }^{\circ}$ journal and benefit from:}

- Convenient online submission

- Rigorous peer review

- Open access: articles freely available online

- High visibility within the field

- Retaining the copyright to your article

Submit your next manuscript at $\boldsymbol{\Delta}$ springeropen.com 